\title{
The prepositional expression of cause in Greek non-literary papyri of the Imperial Period
}

Expression de la cause prépositionnelle dans les papyrus grecs non littéraires de la période impériale

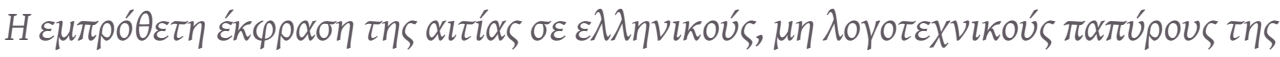

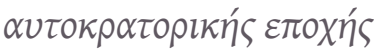

\section{Eleni Tsitsianopoulou}

\section{(2) OpenEdition}

\section{Journals}

Electronic version

URL: https://journals.openedition.org/ceb/15109

DOI: $10.4000 /$ ceb. 15109

ISSN: 2261-4184

Publisher

INALCO

\section{Printed version}

ISBN: 9782858313341

ISSN: 0290-7402

\section{Electronic reference}

Eleni Tsitsianopoulou, "The prepositional expression of cause in Greek non-literary papyri of the Imperial Period", Cahiers balkaniques [Online], 46 | 2020, Online since 08 January 2020, connection on 06 July 2021. URL: http://journals.openedition.org/ceb/15109 ; DOI: https://doi.org/10.4000/ceb. 15109 


\title{
The prepositional expression of cause in Greek non-literary papyri of the Imperial Period
}

\author{
Expression de la cause prépositionnelle dans les \\ papyrus grecs non littéraires de la période impériale

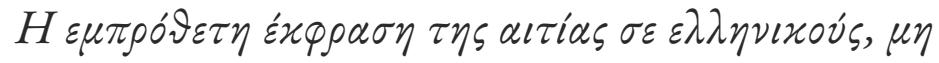

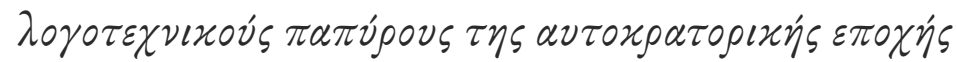

Eleni Tsitsianopoulou National and Kapodistrian University of Athens, Faculty of Philology

\section{Introduction}

This study is exclusively based on a corpus of approximately 30000 Greek non-literary papyri texts and ostraca of the period under consideration.

The cause as a prepositional function is expressed by genitive, dative, accusative, by prepositional phrases, by causal participle and by causal relative clause. Prepositions and cases are closely linked. "There are similarities between prepositions and cases. Ancient Greek prepositions were linked to nouns inflected

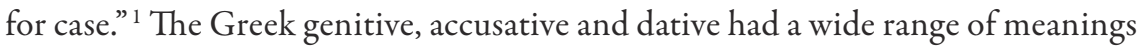
including cause. Quite often, in the papyri texts, it is expressed in a prepositional manner. The prepositional cause of the papyri is expressed either with prepositions or improper prepositions. The prepositions appear in composition with verbs. They are also used as independent words, to connect nouns with other parts of the sentence. Besides these prepositions, there are certain adverbs used in the same way, which cannot be combined with verbs. They are called improper prepositions. ${ }^{2}$ The paper is devoted to the prepositional formulation of cause with

1. Bortone, 2010, p. 110.

2. Goodwin, 1930, §1199, p. 254. 
prepositions and then with the improper prepositions in the papyri texts of the Imperial period.

\section{The cause formulation with prepositions with two cases}

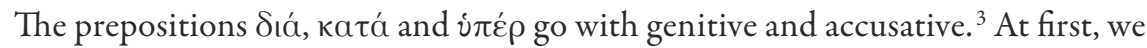
will analyze examples of texts in which there are two-minded prepositions ( $\delta$ เá

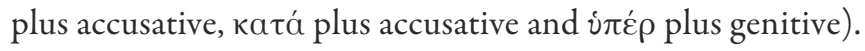

\section{Sı́́ + accusative}

The Greek accusative, in Classical times, was the most common case. ${ }^{4}$ The preposition Sıá, which is often found in the papyri texts of the period under consideration, is sometimes written with accusative of noun, of adjective, with an infinitive with article, ${ }^{5}$ with neutral of pronoun, interrogative, demonstrative to declare a cause. ${ }^{6}$ As it is well known " $\delta$ iá plus accusative occurs in cause expressions and appears to be the most common means for expressing cause." 7

In the following papyri, the preposition Siá plus accusative may precede the identified type ${ }^{8}$ or may follow it. ${ }^{9}$ In P.Oxy. XII 1481 the preposition Sıá goes

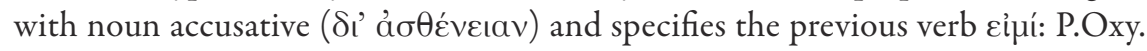

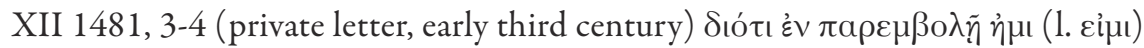

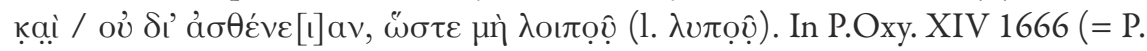
Pap. I 149), 2-3, 14-15 (private letter, third century) at first, the prepositional

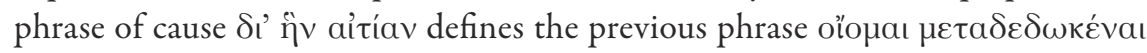

3. KÜHNER \& GERTH 1898-1904, § 433.4, p. 473.

4. Delaunois, 1988, p. 37.

5. MAYSER, 1906-1970, II.1, p. 329-330.

6. HARrison, 1858, p. 191, 208; MAYSER, 1906-1970, II 2, p. 426-427; KüHNER \& Gerth 1898-1904, 434 (p. 484); Thomson, 1960, p. 93.

7. Luraghi, 1989, p. 294.

8. Similarly, we observe in P.Oxy. XXII 2342 (BL VII 148), 25-27 (petition, 16 March,

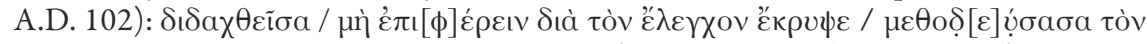

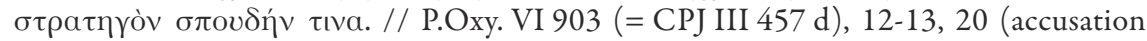

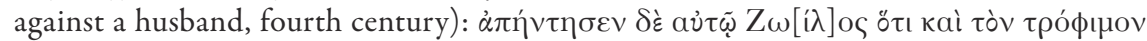

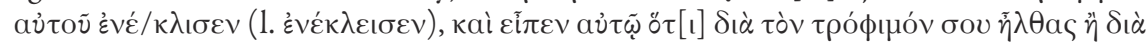

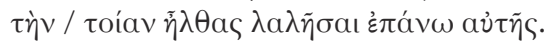

9. Similarly, we see in P.Oxy. IX 1223 (= Sel.Pap. I 164) (BL XI 148), 17-22 (private

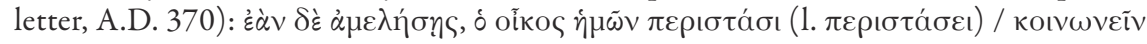

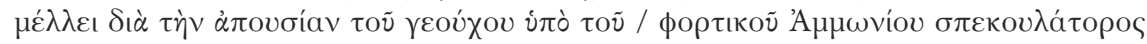

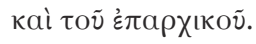




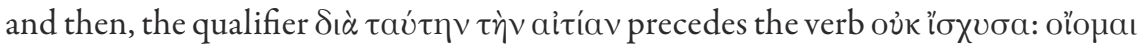

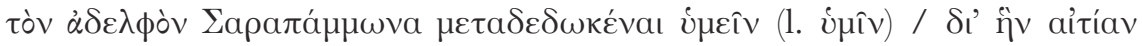

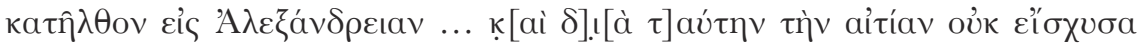

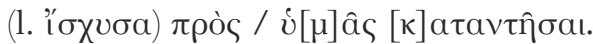

Often, the preposition $\delta$ ia is written with an infinitive with article and follows the defined term as it is shown in the following papyri. ${ }^{10}$ In P.Oxy. XLII 3059 (letter of Didyme to Apollonius, second/third century) the preposition Sıá goes with an infinitive with article $\delta ı \dot{\alpha} \tau \grave{o} \mu \grave{\eta} \beta \lambda \varepsilon \dot{\varepsilon} \varepsilon \sigma \theta a$, defines the previous participle

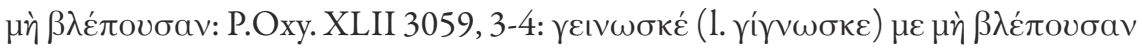

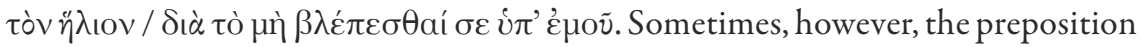
$\delta ı$ with an infinitive with article may precede the identified verbal type, as in P.Oxy. VIII 1133, 11-13 (receipt, 24 March, A.D. 396) in which the prepositional

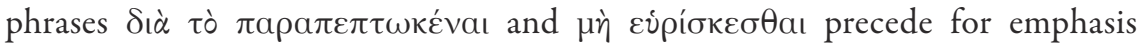

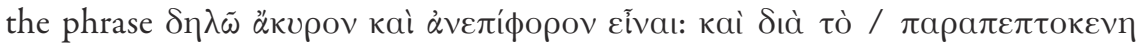

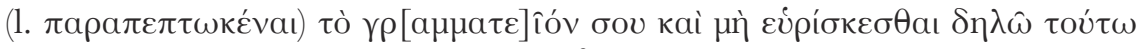

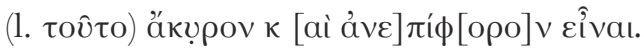

However, both syntactic structures ${ }^{11}$ may appear in the same text as in P.Oxy. LI 3644, 15-21, 30 (letter of Heras ${ }^{12}$ to Papontos, third century), in which the prepositional phrase $\delta$ ì $\tau \dot{\alpha} \mu \dot{\eta} \dot{\alpha} \phi \varepsilon \theta \tilde{\eta} v a$ defines the next verb

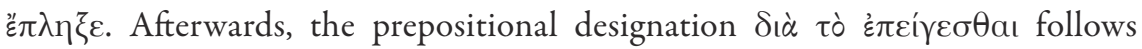

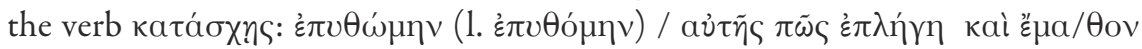

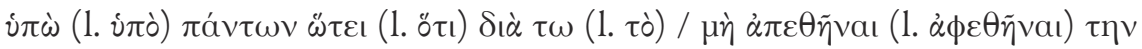

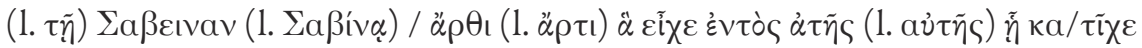

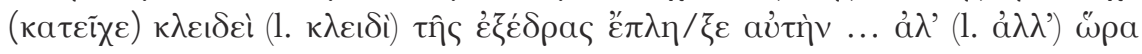

10. Similarly, we observe in P.Oxy. XIV 1636 (= Sel.Pap. I 49), 26-30, 34-37 (contract

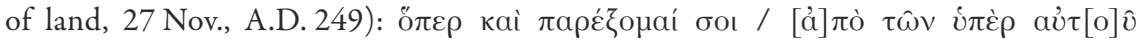

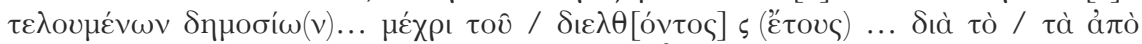

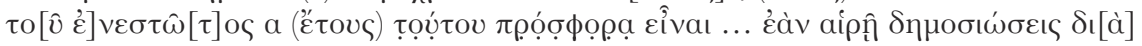

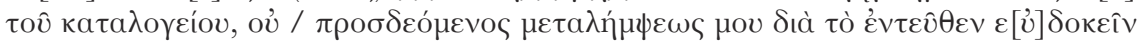

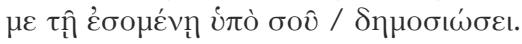

11. We observe the same structure in P.Oxy. VII 1033 (=Chrest.Wilck. $476=$ Sel.

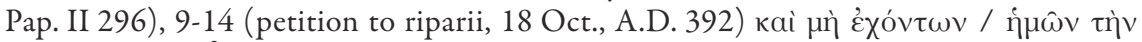

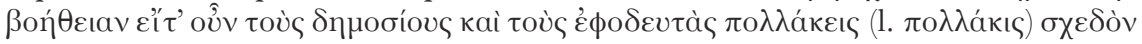

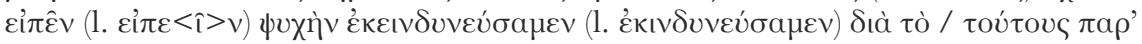

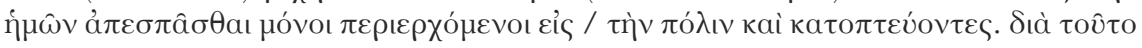

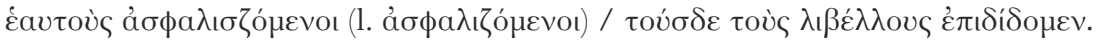

12. Preisigke, 1925, p. 124. 


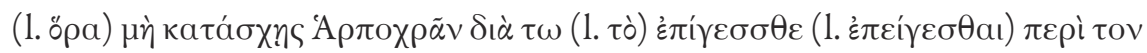

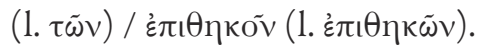

Noteworthy is the next example of P.Oxy. IX 1206 (= Sel.Pap. I 10 = Arangio-Ruiz, FIRA III 16), 10-16 (adoption, 27 March-25 Apr., A.D. 335), in which the preposition $\delta ı$ ia is composed with four infinitives with article a) $\delta i \dot{\alpha}$

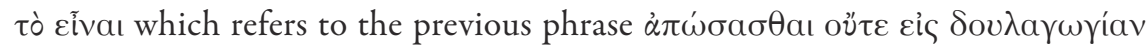

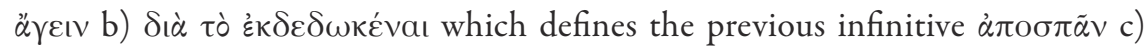

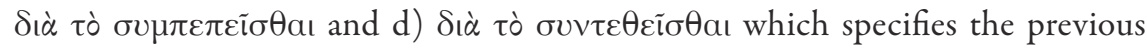

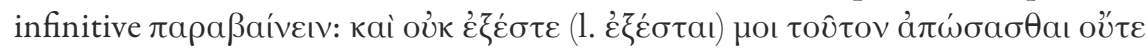

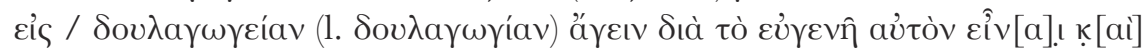

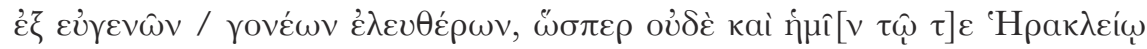

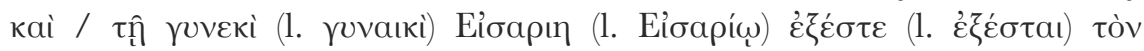

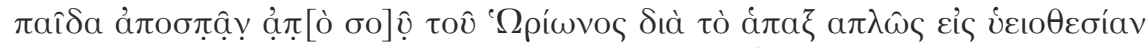

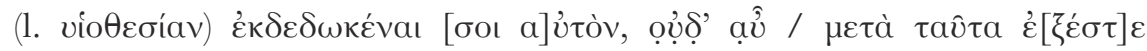

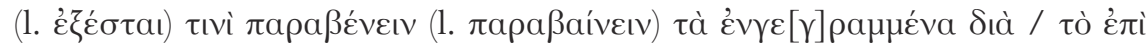

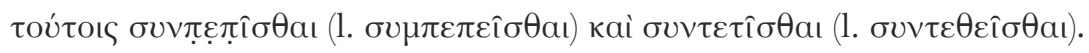

In the following texts, the preposition $\delta$ เá is written with the neutral pronoun, demonstrative, interrogative or personal. The prepositional phrase either follows ${ }^{13}$ or precedes ${ }^{14}$ or is placed between the specified phrase. In the following BGU III 923, the preposition $\delta$ ić is written with an accusative of neutral interrogative pronoun, it is placed at the beginning of the sentence and specifies the verb oủк $\tilde{\eta} \lambda \theta \varepsilon$ : BGU III 923, 19-20 (private letter, first/second century)

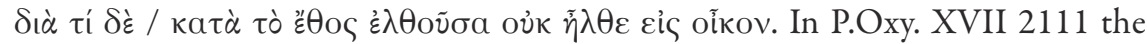

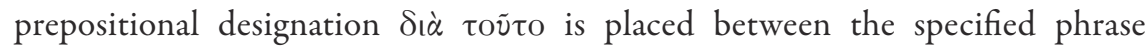

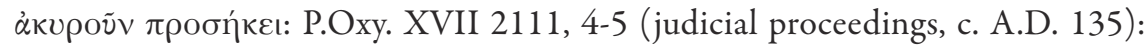

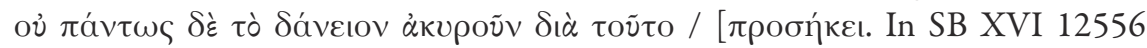
(= BGU IV 1042 = Symposion p. 330), 7-11 (letter of Iulius Agrippinus to his mother Herais ${ }^{15}$ concerning the process of Drusilla, second century) we observe

13. We notice the same construction in P.Oxy. IX 1219, 9-11 (letter of Aristandrus, third

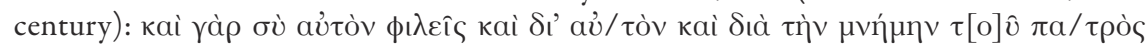
aว่นov̂.

14. We see a similar structure in P.Oxy. XXIV 2407, 44-45 (proceedings of a public

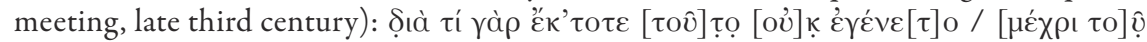

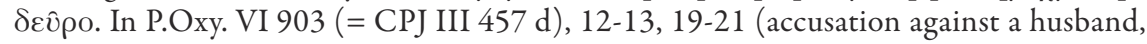

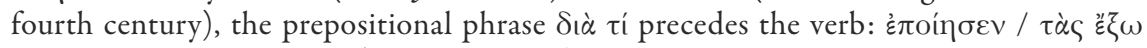

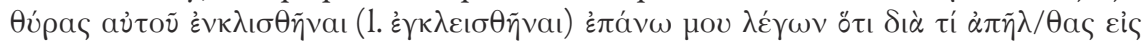

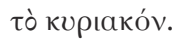

15. Preisigke, 1925, p. 122. 


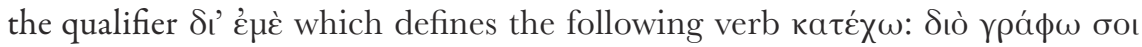

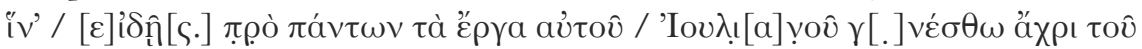

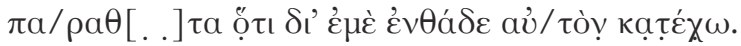

In P.Oxy. LV 3816 (letter of Ptoleminus to Sinthonis, third/fourth century),

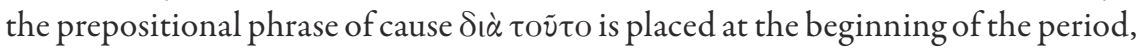

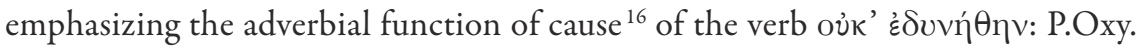

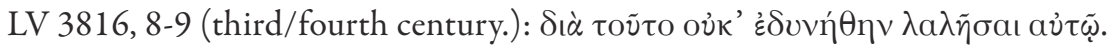

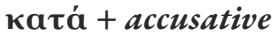

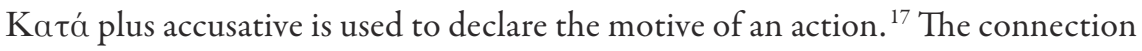
of cause which is prepositionally declared is also found in the following papyri of the third and fourth centuries, which deliver to us texts of minutes: P.Oxy. XXIV 2407, 40 (memoranda of proceedings of a public meeting, late

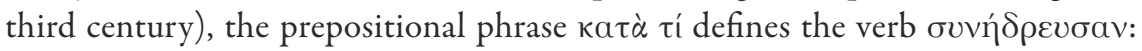

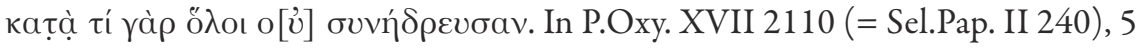
(proceedings of the senate, 6 Oct., A.D. 370), the preposition katá is composed

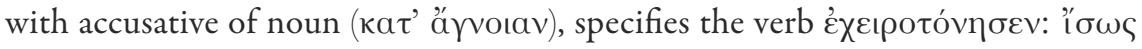

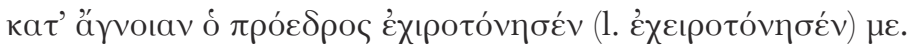

\section{vंrép + genitive}

' $\pi \dot{\varepsilon} \rho$ plus genitive has the signification of "because of, by reason of". ${ }^{18}$ In P.Oxy. XII 1490, 2-4 (letter of Heraclides to an official, c. A.D. 320), the qualifier

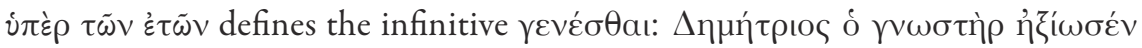

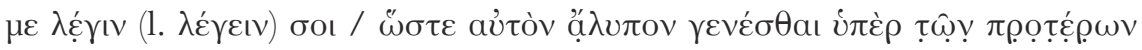
$\dot{\varepsilon} \tau \hat{\omega} \mathrm{v}$.

16. Similarly we observe in P.Oxy. XXXVI 2784 4-6 (private letter, third century): $\delta ı \grave{\alpha}$

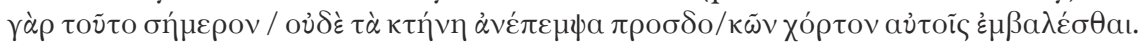

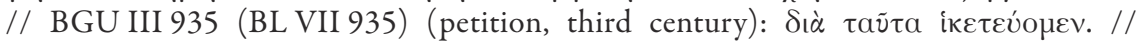

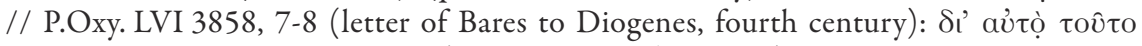

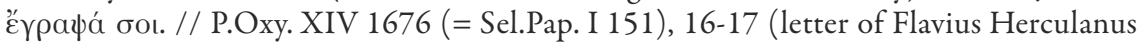

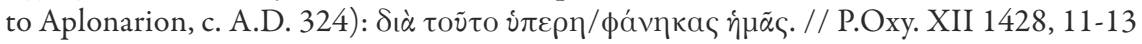

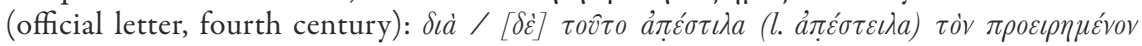
ó $\phi \iota \iota \iota \iota a ́ /[\lambda \iota 0] v$.

17. Harrison, 1858, pp. 337-338; KüHNER \& GERTH 1898-1904, §433.4.b3 (p. 478); SMYTH, 1956, \$1690.2 (p. 380).

18. Harrison, 1858, p.459; KüHner \& Gerth 1898-1904, §435.I.2 (p. 486); SмYтн, 1956, §1697.1 (p. 386). 


\section{The cause formulation with prepositions with three cases}

ع̇í́ + dative ${ }^{19}$

The preposition $\dot{z} \pi$ í is composed with genitive, dative and accusative case. ${ }^{20}$ The preposition $\dot{\varepsilon} \pi$ í plus accusative indicates a cause especially close to verbs

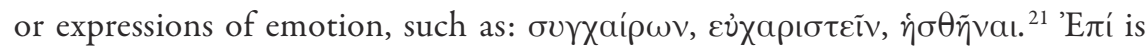
sometimes used to declare the ground or reason of an action. ${ }^{22}$ To declare the cause in the papyri of the second up to the fourth century the prepositional phrase $\varepsilon \pi$ í plus dative is preferred. In P.Oxy. XXII 2342, 3-7 (petition, A.D. 16 March, 102),

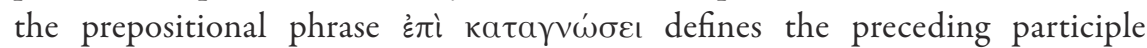

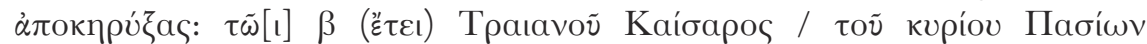

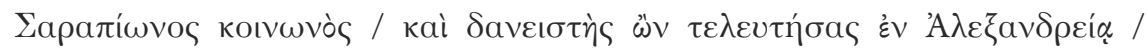

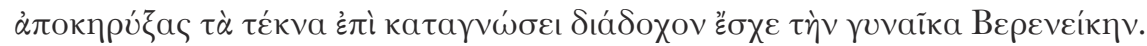
In P.Oxy. LIX 3992, 22-26 (letter of Aelius Theon to Herminus, second

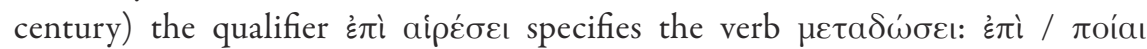

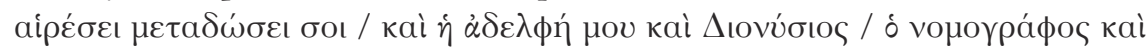

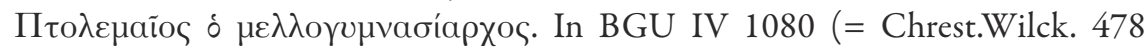
= Hengstl, Griechische Papyri 75), 2-4 (private letter, third century), the prepositional phrase $\dot{\varepsilon} \pi \grave{\imath} \sigma \nu \mu \beta \iota \omega \sigma \sigma \varepsilon$ defines the participle of emotion

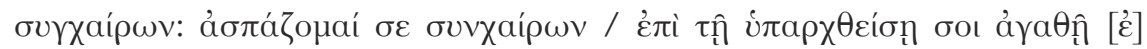

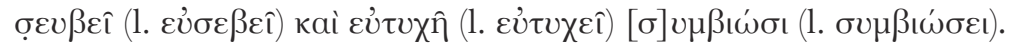

In papyri texts of the third century the preposition $\dot{z} \pi$ í goes with dative of demontstrative pronoun, infinitive with article or noun. It usually identifies a previous verbal form of emotion. In P.Oxy. XXXI 2610 (= Pap.Agon. 5), 2-3 (unknown text type, late third century), the preposition $\dot{\varepsilon} \pi$ í plus dative of

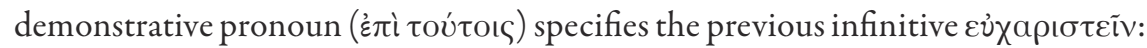

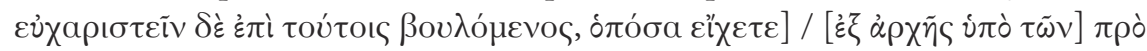

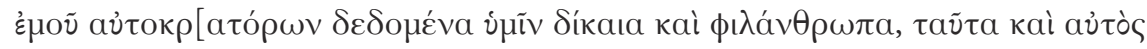

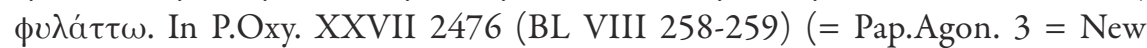
documents illustrating early christianity 9 p. 67-68 n. 23), 7-10 (private letter,

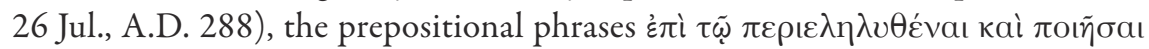
specify the previous infinitive of emotion $\dot{\eta} \sigma \theta \tilde{\eta} v a$. Additionally, the prepositional

19. Kühner \& Gerth, 1898-1904, § 438 II.3 (p. 500-503); Sмyth, 1956, § 1689.2 (p. 378-379).

20. MAYser, 1906-1970, II.2 p. 462.

21. KÜHNER \& GERTH, 1898-1904, §438 II.3d, p. 502.

22. Harrison, 1858, 261, p. 286-287. 
phrase દ̇ं

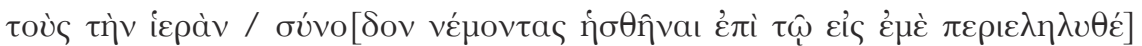

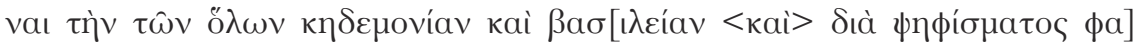

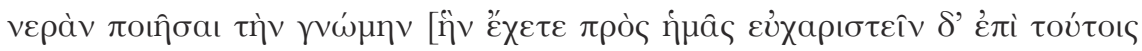

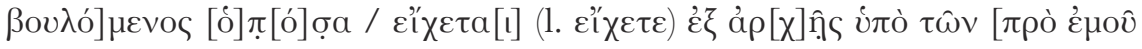

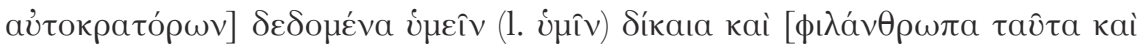

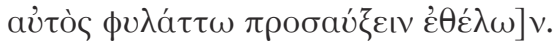

\section{Improper prepositions}

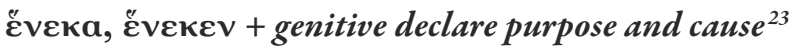

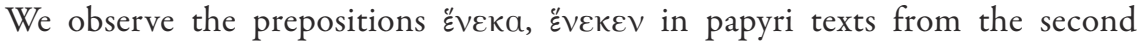

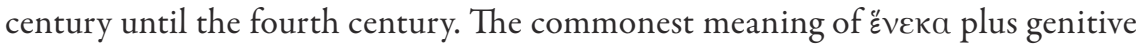

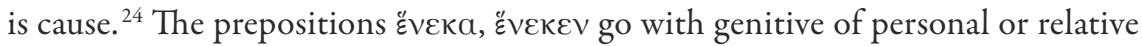
pronoun and noun. We often see anastrophe of preposition.

In P.Oxy. LV 3810, 7-8 (letter of Callias to Cyrilla, second/third century), there is an anastrophe of preposition, the preposition हैveкa is composed with

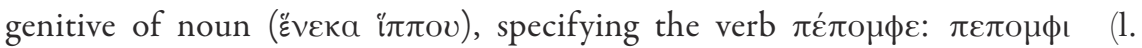

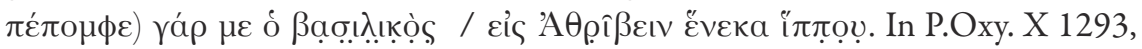
16-17 (letter of Theon, 24 Jul., A.D. 118-138), the preposition हैvعкa goes with genitive of personal pronoun and noun or adjective. The two prepositional

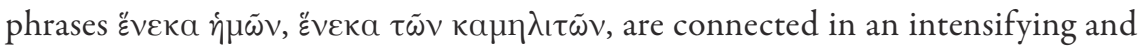

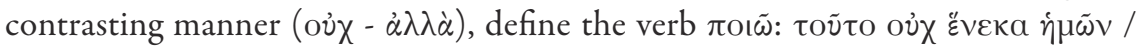

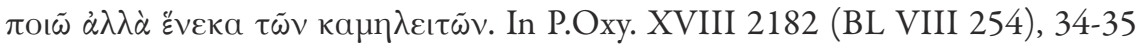
(letter of a strategus, 19 Apr., A.D. 165) from Ptolemais Euergetis (Arsinoites),

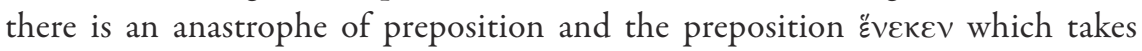

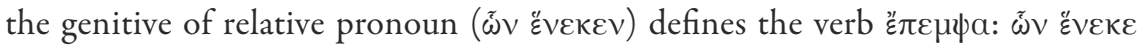

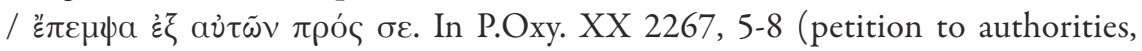
A.D. 360), there is also an anastrophe of preposition in the prepositional phrases

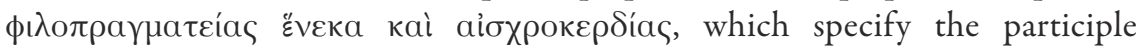

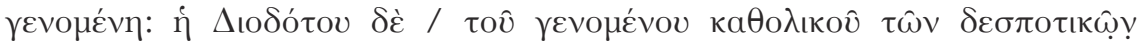

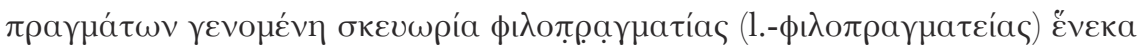

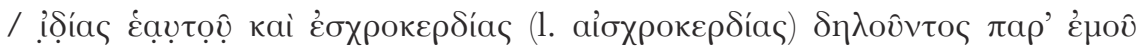

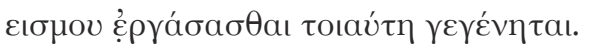

23. SмYтн, 1956, §1700, p. 388.

24. Bortone, 2010, p. 119. 
254 Politique et sociétés à Chypre aujourd'hui

\section{$\chi$ ápıv + genitive ${ }^{25}$}

In P.Oxy. XXII 2342 (petition to authorities, second century) we also observe an anastrophe of preposition. The preposition xápıv composed with the

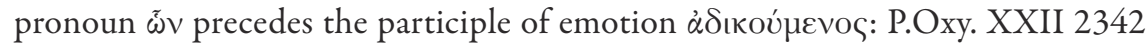

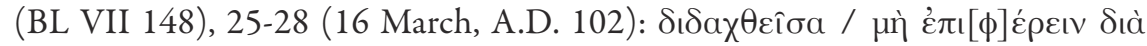

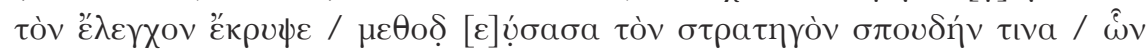

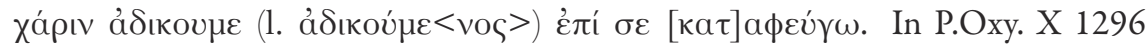
(= Sel.Pap. I 137), 5-7 (letter of Dius, third century), the preposition xápıv with

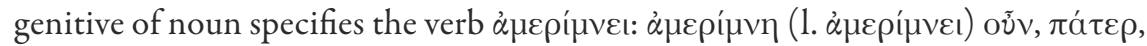

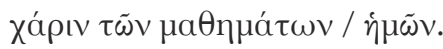

\section{Conclusion}

In the documents of Imperial era, prepositional phrases of cause are often found in private letters and in petitions to the authorities. They are also attested in other types of documents, such as contracts, adoption documents, receipts, complaints, judicial proceedings, memoranda, minutes of proceedings of a public meeting. In most examples, the prepositional phrases are with articles. They usually follow the specified terms. In a few examples they precede the terms to which they refer for emphasis. Prepositional qualifiers of cause are mostly attested in the second, third and fourth centuries A.D.

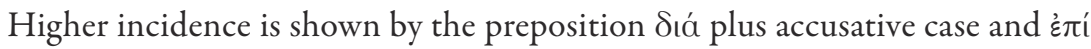

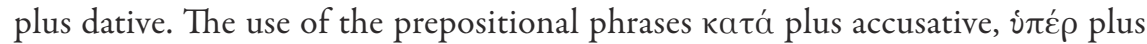

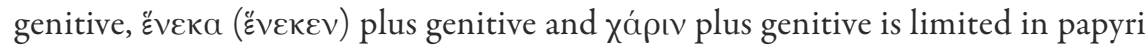
texts of the era under consideration. In some examples, there may be a verbal form of emotion, denoting the causal relationship. The cause in the Imperial Period as well as in the early Arabic Period is mainly expressed in documentary papyri by subordinate causal clauses.

\section{BIBLIOGRAPHY}

\section{Books}

Bortone Pietro, 2010, Greek Prepositions from Antiquity to the Present, Oxford University Press, Oxford, 362 p. 
Delaunois Marcel, 1988, Essai de syntaxe grecque classique, Publications des facultés universitaires Saint-Louis, Bruxelles, 220 p.

Goodwin William Watson, 1930, A Greek Grammar, Gulick Charles Burton (ed.), Ginn and Company, Boston, 491 p.

Harrison Gessner, 1858, A Treatise on the Greek Prepositions, and on the Cases of Nouns with which these Are Used, J. B. Lippincott \& Co, Philadelphia, 170 p.

KüHner Raphael \& GerTh Bernhard, 1898-1904, Aüsführliche Grammatik der Griechischen Sprache, zweiter Teil: Satzlehre, zweiter Band, reprinted in 1966 Hannover-Leipzig, Hahnsche buchhandlung, Hannover.

Mayser Edwin, 1906-1970, Grammatik der griechischen Papyri aus der Ptolemäerzeit mit Einschluss der gleichzeitiden Ostraka und der in Ägypten verfassten Inschriften, De Gruyter, Berlin-Leipzig.

Preisigke Friedrich \& Kiessling Emil, 1925, I, A-K, II, L-W, Wörterbuch der griechischen Papyrusurkunden, mit Einschluss der griechischen Inschriften, Aufschriften, Ostraka, Mumienschilder usw. aus Ägypten, Selbstverlag der Erben, Berlin.

SCHwyzer Eduard, 1939, Erster Band: Griechische Grammatik. 1950, Zweiter Band: Syntax und Syntaktische Stilistik, vervollständigt und herausgegeben von Debrunner A., C.H. Beck, München.

Sмyтн Herbert Weir, 1956, Greek Grammar, Harvard University Press, Cambridge Massachusetts, 802 p.

Thomson George, 1960, The Greek Language, W. Heffer and Sons Ltd, Cambridge, $108 \mathrm{p}$.

\section{Papers, contributions to books}

Luraghi Sylvia, 1989, "Cause and Instrument expressions in Classical Greek, Remarks on the use of Sıá in Herodotus and Plato", Mnemosyne, XLII, 3-4, pp. 294-307. 


\section{Webography}

http://www.papyri.info/

http://www.rzuser.uni-heidelberg.de/ gv0/

Abstract: This paper deals with the statement of cause in Greek documentary papyri of the Imperial Period. It studies the frequency of occurrence of the adverbial designations, the detection of their position within the clauses and the identification of the terms they define in Greek non-literary papyri from 31 B.C. until $4^{\text {th }}$ century. The examples come from a body of approximately $30000 \mathrm{Greek}$ non-literary papyri texts and ostraca. The search of the material was based on the online database Duke Databank of Documentary Papyri (DDbDP), which includes all the documentary papyri. In order to avoid possible mistakes in electronic publications, the papyri texts were also checked by the printed volumes of texts.

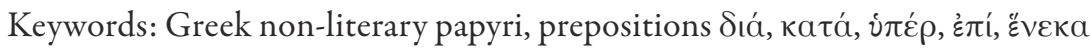

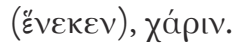

Résumé: cet article traite de la locution prépositive de cause, présente dans les papyrus grecs de l'ère impériale. Le texte étudie la fréquence d'apparition des déterminants adverbiaux, relève leur place dans les phrases et reconnaît des termes qu'elles définissent dans les papyrus grecs non littéraires à partir de 31 av. J.-C. jusqu'au $I V^{*}$ siècle apr. J.-C. Les exemples proviennent d'un corpus d'environ 30000 papyrus et ostracons grecs non littéraires. La recherche du matériel a été basée sur la base de données en ligne Duke Databank of Documentary Papyri (DDbDP), qui comprend tous les documents papyrus. Afin d'éviter d'éventuelles erreurs dans les publications électroniques, les textes papyrus ont également été révisés à l'aide de volumes déjà édités.

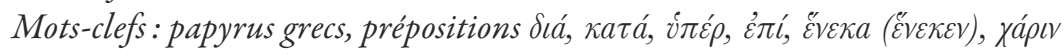

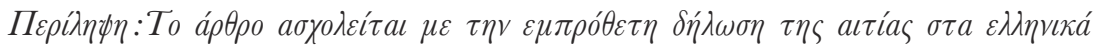

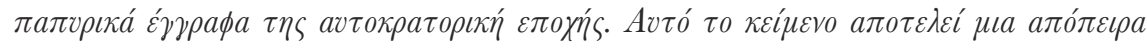

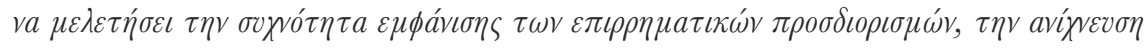

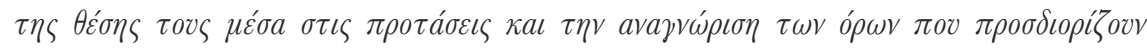

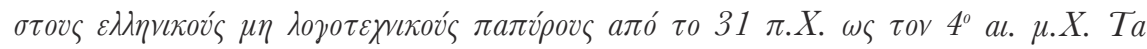

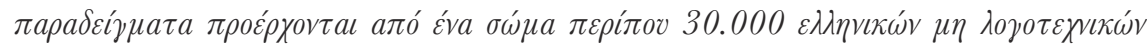


THE PREPOSITIONAL EXPRESSION OF CAUSE

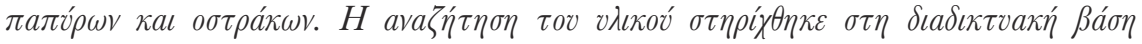

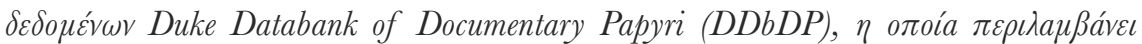

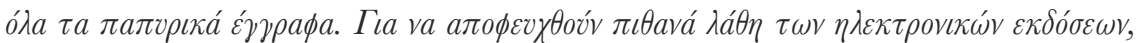

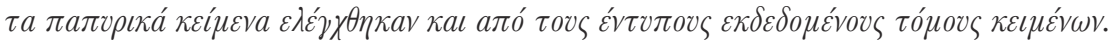

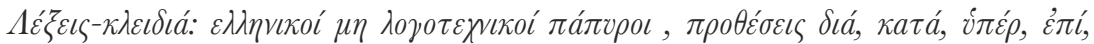

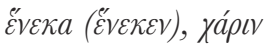

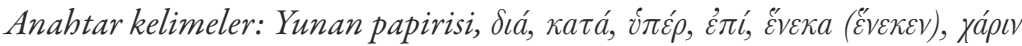

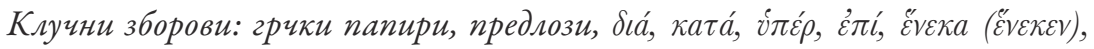
xápıv 